\title{
Effects of $\mathrm{H}_{2} \mathrm{O}$ on the thermal and photocatalytic reactions of ethane on supported $\mathrm{Au}$
}

\author{
Anita Tóth, Tamás Bánsági, Frigyes Solymosi* \\ MTA-SZTE Reaction Kinetics and Surface Chemistry Research Group, Rerrich Béla tér 1, H-6720, Szeged, Hungary
}

\section{A R T I C L E I N F O}

\section{Article history:}

Received 30 May 2017

Received in revised form 4 July 2017

Accepted 9 July 2017

\section{Keywords:}

Photo-induced decomposition of ethane

Effects of $\mathrm{H}_{2} \mathrm{O}$

Production of $\mathrm{H}_{2}$ and $\mathrm{C}_{2} \mathrm{H}_{4}$

$\mathrm{TiO}_{2}$-supported Pt metals

\begin{abstract}
A B S T R A C T
The effect of illumination on the $\mathrm{H}_{2} \mathrm{O}+\mathrm{C}_{2} \mathrm{H}_{6}$ reaction was investigated on Au deposited on $\mathrm{TiO}_{2}, \mathrm{ZnO}$ and $\mathrm{CeO}_{2}$ samples. Whereas the photocatalytic decomposition of ethane is very limited even on the most active pure $\mathrm{TiO}_{2}$ : the conversion was only $4 \%$ at $300 \mathrm{~K}$ in $210 \mathrm{~min}$, the deposition of Au metal onto $\mathrm{TiO}_{2}$ markedly enhanced the rate of photo-induced decomposition of $\mathrm{C}_{2} \mathrm{H}_{6}$. Addition of $\mathrm{H}_{2} \mathrm{O}$ to ethane further enhanced the conversion and led to the production of $\mathrm{H}_{2}$. The highest conversion of ethane, 23.5\% was measured for $\mathrm{Au} / \mathrm{TiO}_{2}$. Ethylene was not detected even in traces, indicating the complete degradation of $\mathrm{C}_{2} \mathrm{H}_{6}$ to $\mathrm{H}_{2}$ and carbon containing deposit. Temperature programmed reaction (TPR) measurements revealed that the carbonaceous deposit on the catalysts is very stable. On $\mathrm{Au} / \mathrm{TiO}_{2}$ it reacted with $\mathrm{H}_{2}$ to give $\mathrm{CH}_{4}$ at $\mathrm{Tp}=453$ and $604 \mathrm{~K}$ and $\mathrm{C}_{2} \mathrm{H}_{6}$ and $\mathrm{C}_{3} \mathrm{H}_{8}$ with $\mathrm{Tp}=602 \mathrm{~K}$. The promoting effect of metals was explained by a better separation of charge carriers induced by illumination and by the enhanced electronic interaction between metals and $\mathrm{TiO}_{2}$.
\end{abstract}

(c) 2017 Elsevier B.V. All rights reserved.

\section{Introduction}

A great attempt is being made to obtain hydrogen in economical ways. Besides the water-gas shift process, the catalytic decomposition of $\mathrm{C}-\mathrm{H}$ compounds is the most suitable source of $\mathrm{H}_{2}$ production [1-8]. Although dispersed metals are effective catalysts for the decomposition of methane and ethane, their reactions need high temperature, and we can count with the deposition of carbon leading to the deactivation of the catalysts. As in other cases the reaction can be accelerated by illumination [8-19]. The rate of the photocatalytic reaction can be further increased by using another reaction partner, $\mathrm{CO}_{2}$ or $\mathrm{H}_{2} \mathrm{O}$, which may react with the hydrocarbons and/or with the carbon deposition, thereby enhancing the production of $\mathrm{H}_{2}$ [20].

There is a growing interest in establishing how the defect structure and electric properties of oxidic supports influence the catalytic performance of deposited metals [21,22]. This interest can be led back to the early findings, namely that changing the electric conductivity of n-type $\mathrm{TiO}_{2}$ markedly influences the catalytic efficiency of metals deposited on its surface [23-27]. The electric structure of the support was found to be decisive in the different types of reactions, such as photocatalytic decomposition

\footnotetext{
* Corresponding author.

E-mail address: fsolym@chem.u-szeged.hu (F. Solymosi).
}

of dimethyl ether [16], in the reaction of ethane with $\mathrm{CO}_{2}$ [7], in the hydrogenation of $\mathrm{CO}_{2}$ [20], and in the production of $\mathrm{H}_{2}$ in the photocatalytic reactions of ethane [15].

In the present work an account is given on the $\mathrm{H}_{2} \mathrm{O}$-promoted thermal and photocatalytic decomposition of ethane at $300 \mathrm{~K}$. The catalyst chosen is supported $\mathrm{Au}$, which was deposited on various semiconduction oxides, such as $\mathrm{TiO}_{2}, \mathrm{ZnO}$ and $\mathrm{CeO}_{2}$.

\section{Experimental}

\subsection{Methods}

Catalytic measurements were carried out in a fixed bed continuous flow reactor made of a quartz tube. The flow rate of reactant gases was $12 \mathrm{ml} / \mathrm{min}$. The exit gas was analysed by gas chromatograph (Hewlett-Packard 5890) on a Porapak QS column. The carrier gas was $\mathrm{Ar}$ which contained $12.5 \%$ of $\mathrm{C}_{2} \mathrm{H}_{6}$. In the study of $\mathrm{H}_{2} \mathrm{O}+\mathrm{C}_{2} \mathrm{H}_{6}$ reaction we applied a gas mixture of $1: 1 \mathrm{~mol}$ ratio.

The photocatalytic reaction was followed in the same way as described in our previous paper [7]. The reactor was equipped with a $500 \mathrm{~W}$ medium pressure mercury vapor lamp (TQ 718, Heraeus Noble light, Germany) as a light source. The approximate light intensity at the catalyst films is $59.4 \mathrm{~mW} / \mathrm{cm}^{2}$. The photoreactor (volume: $670 \mathrm{ml}$ ) consists of two concentric quartz glass tubes fitted one into the other and a centrally positioned lamp. It is connected to a gas-mixing unit serving for the adjustment of 


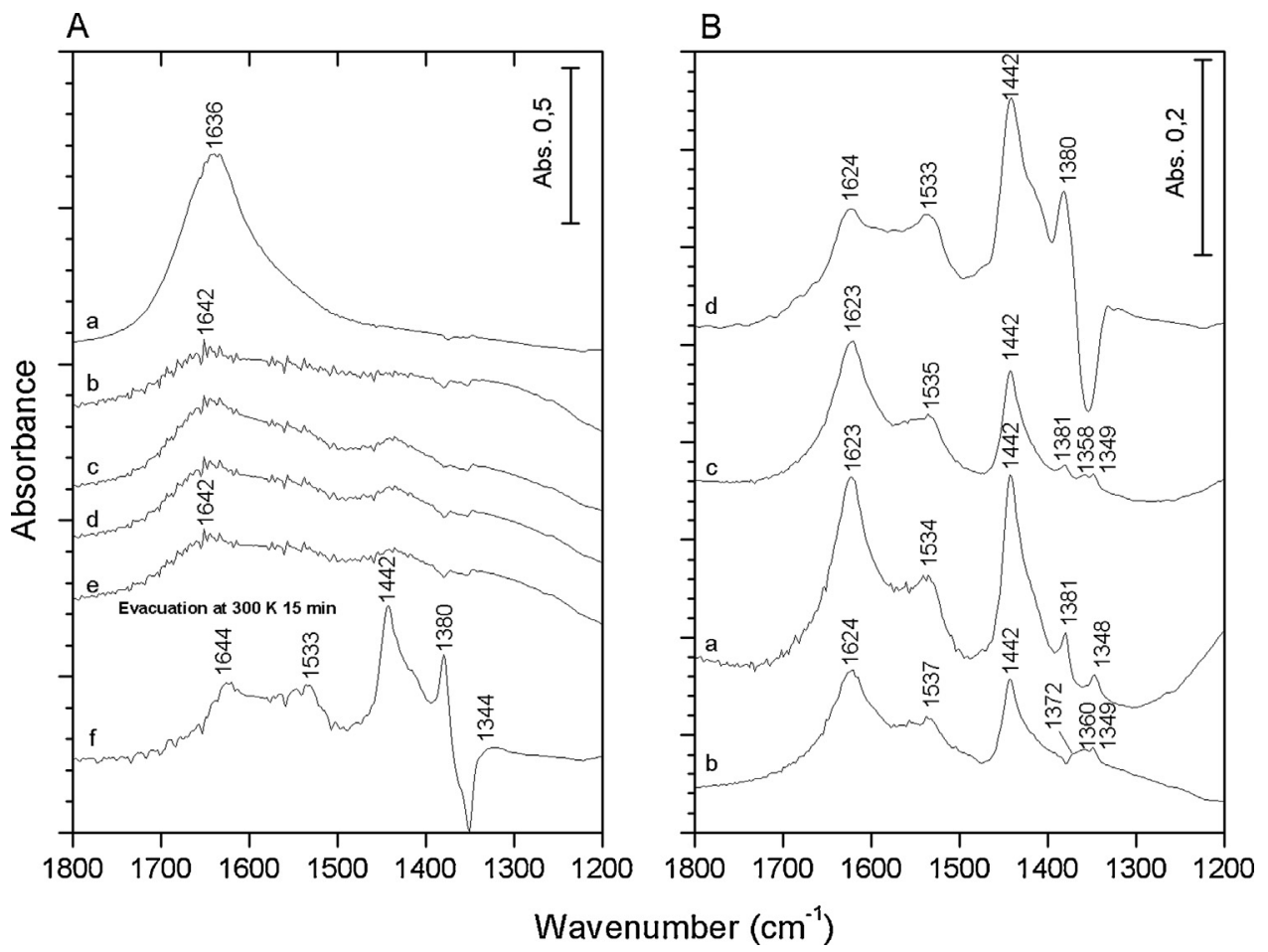

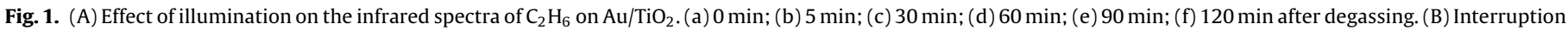
of experiment and degassing the sample (a) after 15 (min): (b) $30 \mathrm{~min}$; (c) $60 \mathrm{~min}$; (d) $120 \mathrm{~min}$.

the composition of the gas or vapor mixtures to be photolyzed in situ. The carrier gas was $\mathrm{Ar}$ which was mixed with $\mathrm{C}_{2} \mathrm{H}_{6}(\sim 1.5 \%$, $330 \mu \mathrm{mol})$. In the study of the effects of $\mathrm{H}_{2} \mathrm{O}$, its amount was varied between $\sim 1.5-4.5 \%$. The gas-mixture was circulated by a diaphragm pump. The reaction products were analysed with an Agilent 4890 gas chromatograph equipped with PORAPAK $1 / 2 \mathrm{Q}+$ PORAPAK $1 / 2 \mathrm{~S}$ packed and Equity-1 capillary columns. The volume of the sampling loop of the GC was $500 \mu$ l. The amount of all products was related to this loop. The conversion of $\mathrm{C}_{2} \mathrm{H}_{6}$ was calculated taking into account the amount of $\mathrm{C}_{2} \mathrm{H}_{6}$ consumed. This value agreed well with that based on the $\mathrm{H}$ basis, e.g. taking into account the $\mathrm{H}$ content of the $\mathrm{C}_{2} \mathrm{H}_{6}$ and the amount of $\mathrm{H}_{2}$ formed.

For FTIR studies a mobile IR cell housed in a metal chamber was used [15]. Infrared spectra were recorded with a Biorad (Digilab. Div. FTS 155) instrument. Samples were illuminated by the full arc of a Hg lamp (100 W LPS-220, PTI) outside the IR sample compartment. The filtered light passed through a high-purity $\mathrm{CaF}_{2}$ window into the cell. All the spectra presented in this study are difference spectra.

In the temperature programmed desorption (TPD) studies the heating rate was $5 \mathrm{~K} / \mathrm{ml}$ and the flow rate of Ar was $20 \mathrm{ml} / \mathrm{min}$.

\subsection{Materials}

$1 \% \mathrm{Au} / \mathrm{TiO}_{2}$ and $1 \% \mathrm{Au} / \mathrm{ZnO}$ catalysts were purchased from STREM Chem. Inc. Average gold crystallite size is $\sim 2-3 \mathrm{~nm}$. Other supported Au catalysts were prepared by a depositionprecipitation method. $\mathrm{HAuCl}_{4} \times$ aq (p.a., $49 \%$ Au, Fluka AG) was first dissolved in triply distilled water. After the $\mathrm{pH}$ of the aqueous $\mathrm{HAuCl}_{4}$ solution had been adjusted to 7.5 by the addition of $1 \mathrm{M}$ $\mathrm{NaOH}$ solution, a suspension was prepared with the finely powdered oxidic support, and the system was kept at $343 \mathrm{~K}$ for $1 \mathrm{~h}$ under continuous stirring. The suspension was then aged for $24 \mathrm{~h}$ at room temperature, washed repeatedly with distilled water, dried at $353 \mathrm{~K}$ and calcined in air at $573 \mathrm{~K}$ for $4 \mathrm{~h}$. The other oxides used as supports were: $\mathrm{CeO}_{2}$ (Alfa Aesar) and $\mathrm{MgO}$ (Reanal). The average gold crystallite size in these samples is $5-8 \mathrm{~nm}$. The surface area of the catalysts was determined by BET method with $\mathrm{N}_{2}$ adsorption at $\sim 100 \mathrm{~K}$. The dispersion of metals was determined by the adsorption of $\mathrm{H}_{2}$ at room temperature.

\section{Results and discussion}

\subsection{IR spectroscopic studies}

In a previous paper we demonstrated that deposition of Pt metals onto $\mathrm{TiO}_{2}$ only slightly influenced the absorption spectra of $\mathrm{C}_{2} \mathrm{H}_{6}$ at the room temperature [15]. In the case of $\mathrm{Au} / \mathrm{TiO}_{2}$ the adsorption of $\mathrm{H}_{2} \mathrm{O}+\mathrm{C}_{2} \mathrm{H}_{6}$ produced absorption bands at 3001, 2963, 2952, 2928, 2890, 2870 and $1636 \mathrm{~cm}^{-1}$, which agreed well with those obtained for pure $\mathrm{TiO}_{2}$ [15]. Illumination only slightly affected the positions of the above absorption bands. After flushing the $\mathrm{C}_{2} \mathrm{H}_{6}+\mathrm{H}_{2} \mathrm{O}$ mixture absorption bands at 2972,2935 and $2868 \mathrm{~cm}^{-1}$ remained in the high frequency region. New spectral features were detected at $1662,1533,1442,1380$ and $1344 \mathrm{~cm}^{-1}$ in the low frequency range, which we attribute to the different vibrations of adsorbed $\mathrm{C}_{2} \mathrm{H}_{4}$ and $\mathrm{C}_{2} \mathrm{H}_{\mathrm{x}}$ fragments formed in the photocatalytic reaction (Fig. 1A). As these absorption bands were seen only after evacuating the gas phase, in order to see the development of these bands the cell was evacuated at various times. Spectra obtained are shown in Fig. 1B. Accordingly, the above bands developed at very early stage of the photoreaction and they became somewhat larger with the increase of illumination time.

\subsection{TPD measurements}

Following the adsorption of $\mathrm{C}_{2} \mathrm{H}_{6}$ on $\mathrm{Au} / \mathrm{TiO}_{2}$ a very small amount of $\mathrm{C}_{2} \mathrm{H}_{4}$ desorbed first with $\mathrm{Tp} \sim 363 \mathrm{~K}$, followed by $\mathrm{C}_{2} \mathrm{H}_{6}$ $(\mathrm{Tp}=753 \mathrm{~K})$ and $\mathrm{CH}_{4}(\mathrm{Tp}=723 \mathrm{~K})$. A larger amount of $\mathrm{H}_{2}$ was released above $600 \mathrm{~K}$ with a peak of 663 and $993 \mathrm{~K}$ (Fig. 2). Adsorbing $\mathrm{H}_{2} \mathrm{O}+\mathrm{C}_{2} \mathrm{H}_{6}$ gas mixture over $\mathrm{Au} / \mathrm{TiO}_{2}$ gave $\mathrm{CH}_{4}(\mathrm{Tp}=753$ and $903 \mathrm{~K})$ and a smaller amount of $\mathrm{C}_{2} \mathrm{H}_{4}(\mathrm{Tp}=753 \mathrm{~K}) . \mathrm{H}_{2}$ desorbed with 

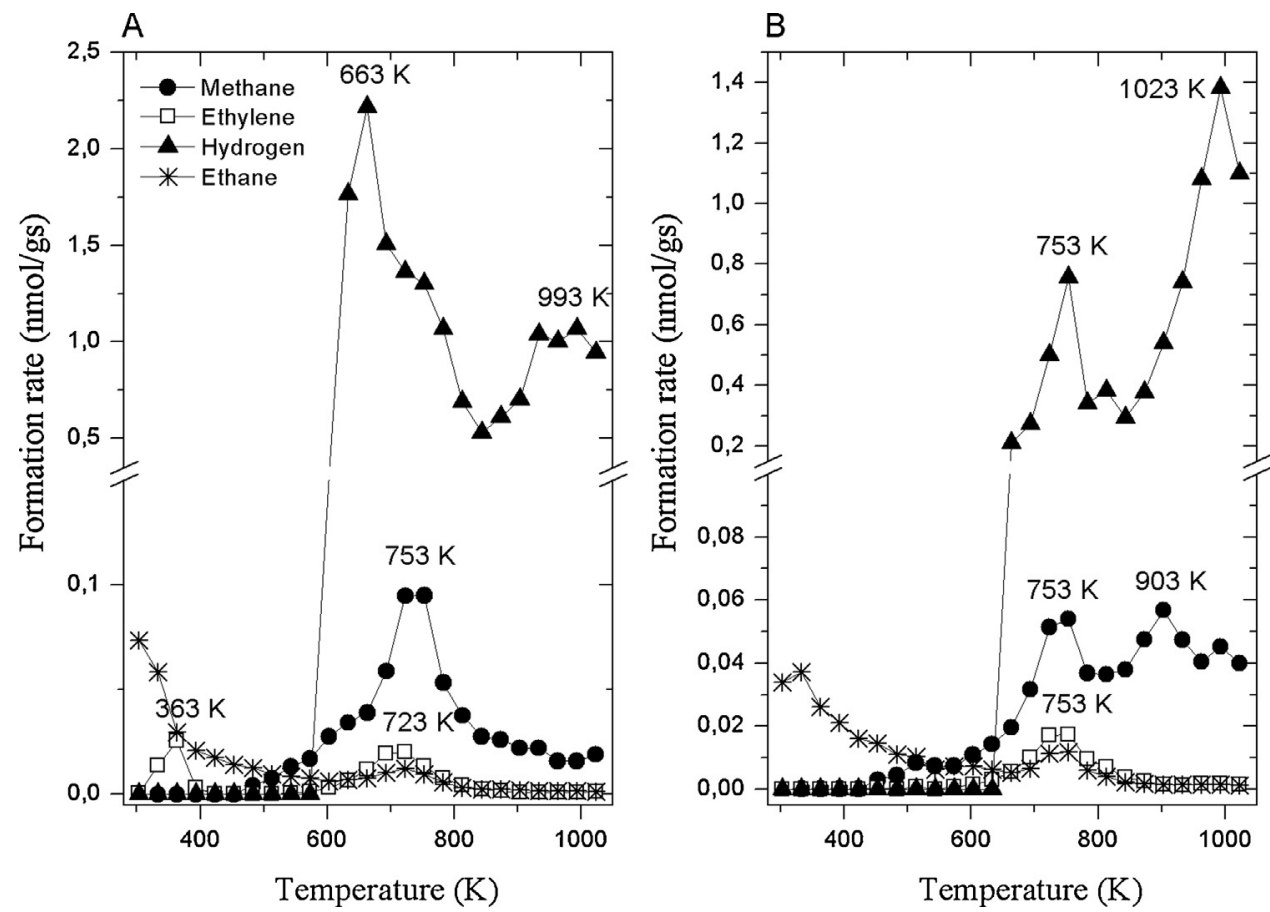

Fig. 2. Temperature programmed desorption of $\mathrm{C}_{2} \mathrm{H}_{6}$ following its adsorption over $\mathrm{Au} / \mathrm{TiO}_{2}(\mathrm{a})$ in the absence of $\mathrm{H}_{2} \mathrm{O}$; (b) in the presence of $\mathrm{H}_{2} \mathrm{O}$.

$\mathrm{T}_{\mathrm{p}}=753$ and $1023 \mathrm{~K}$. A very small amount of $\mathrm{C}_{2} \mathrm{H}_{6}$ continuously released above $300 \mathrm{~K}$ up to $\sim 850 \mathrm{~K}$.

The fact that the amount of $\mathrm{H}_{2}$ desorbed is incomparably larger than that of $\mathrm{C}_{2} \mathrm{H}_{4}$ suggests the occurrence of the following reactions

$\mathrm{C}_{2} \mathrm{H}_{6}=\mathrm{C}_{2} \mathrm{H}_{4}+\mathrm{H}_{2}$

$\mathrm{C}_{2} \mathrm{H}_{4}=\mathrm{CH}_{4}+\mathrm{C}$

$\mathrm{C}_{2} \mathrm{H}_{4}=2 \mathrm{C}+2 \mathrm{H}_{2}$

The decomposition of $\mathrm{C}_{2} \mathrm{H}_{6}$ starts around $550 \mathrm{~K}$. The desorption of weakly bonded $\mathrm{C}_{2} \mathrm{H}_{6}$ and $\mathrm{C}_{2} \mathrm{H}_{4}$ occurs slightly above $300 \mathrm{~K}$. The main feature of TPD curves remain the same when $\mathrm{H}_{2} \mathrm{O}$ was added to $\mathrm{C}_{2} \mathrm{H}_{6}$. Qualitatively similar TPD curves were obtained for $\mathrm{Au} / \mathrm{ZnO}$.

\subsection{Thermal catalytic reaction}

Fig. 3 shows the results obtained for the thermal decomposition of ethane as a function of temperature on various $\mathrm{Au}$ catalysts. Au/ZnO proved to be the most active: the conversion of ethane reached $10 \%$ at $773 \mathrm{~K}$, whereas on other samples this value required higher temperatures to be reached. The product distribution depends on the nature of the supports. On $\mathrm{Au} / \mathrm{TiO}_{2}$ the same amount of $\mathrm{H}_{2}$ and $\mathrm{C}_{2} \mathrm{H}_{4}$ was formed in the whole temperature range, on another Au sample the $\mathrm{H}_{2} / \mathrm{C}_{2} \mathrm{H}_{4}$ ratio was larger than 1 , and a well measurable amount of $\mathrm{CH}_{4}$ was also produced. Adding $\mathrm{H}_{2} \mathrm{O}$ to $\mathrm{C}_{2} \mathrm{H}_{6}\left(\mathrm{H}_{2} \mathrm{O} / \mathrm{C}_{2} \mathrm{H}_{6} \sim 1\right)$ markedly increased the conversion of $\mathrm{C}_{2} \mathrm{H}_{6}$ on all samples (Fig. 4). Its effect was more explicit in the formation of $\mathrm{H}_{2}$. On $\mathrm{Au} / \mathrm{TiO}_{2}$ the amount of $\mathrm{H}_{2}$ increased by a factor of 5 at $950 \mathrm{~K}$. Interestingly, much less enhancement occurred in the production of $\mathrm{C}_{2} \mathrm{H}_{4}$.

\subsection{Photocatalytic reactions}

The photo activity of previously studied Au samples was investigated at $300 \mathrm{~K}$. In the absence of $\mathrm{H}_{2} \mathrm{O}$ the illumination over supported metals led only to a very little, less than $1 \%$ decomposition of ethane. Adding $\mathrm{H}_{2} \mathrm{O}$ to the $\mathrm{C}_{2} \mathrm{H}_{6}\left(\mathrm{H}_{2} \mathrm{O} / \mathrm{C}_{2} \mathrm{H}_{6} \sim 1: 1\right)$ induced only a slight photoreaction either on $\mathrm{Au} / \mathrm{ZnO}, \mathrm{Au} / \mathrm{MgO}$ or on $\mathrm{Au} / \mathrm{CeO}_{2}$. The situation was completely different over $\mathrm{Au} / \mathrm{TiO}_{2}$. A significant amount of $\mathrm{H}_{2}$ evolved and also a smaller amount of $\mathrm{CO}_{2}$. This is shown in Fig. 5A. The slight formation of methane also occurred. On the basis of $\mathrm{H}_{2}$ formed the conversion of ethane approached $25 \%$ in $200 \mathrm{~min}$. The consumption of ethane gave somewhat lower values. For comparison we mention that illumination exerted only very slight effect on the decomposition of $\mathrm{H}_{2} \mathrm{O}$ and $\mathrm{C}_{2} \mathrm{H}_{6}$ alone. In the case of $\mathrm{H}_{2} \mathrm{O}$ we registered only 1-2\% decomposition in $200 \mathrm{~min}$, whereas a larger photoeffect was found for $\mathrm{C}_{2} \mathrm{H}_{6}$ : in 200 min the conversion reached $\sim 5 \%$.

In the explanation of the high photoactivity of $\mathrm{Au} / \mathrm{TiO}_{2}$ we have to take into account that $\mathrm{TiO}_{2}$ is a semiconducting oxide. The fact that on pure $\mathrm{TiO}_{2}$ the illumination caused only a slight increase in the conversion is probably due to the recombination of the charges induced by illumination

$\mathrm{TiO}_{2}+\mathrm{h} v=\mathrm{h}^{+}+\mathrm{e}^{-}$

$\mathrm{h}^{+}+\mathrm{e}^{-}=\mathrm{h} v$

is very fast on $\mathrm{TiO}_{2}$. The deposition of Au metal onto $\mathrm{TiO}_{2}$, however, markedly enhanced the extent of photo-effect of $\mathrm{TiO}_{2}$. This promoting effect of metals in photocatalytic processes is generally explained by the better separation of the charge carriers generated in the primary process $[8,9]$, which provides a greater possibility for the activation of $\mathrm{C}_{2} \mathrm{H}_{6}$

$\mathrm{C}_{2} \mathrm{H}_{6}+\mathrm{e}^{-}=\mathrm{C}_{2} \mathrm{H}_{6}{ }^{\delta-}$

$\mathrm{C}_{2} \mathrm{H}_{6}{ }^{\delta-}=\mathrm{C}_{2} \mathrm{H}_{5(\mathrm{a})}+\mathrm{H}_{(\mathrm{a})}+\mathrm{e}^{-}$

It can be also assumed that the Schottky barrier at $\mathrm{Au} / \mathrm{TiO}_{2}$ interface can function as an efficient barrier preventing electronhole recombination $[10,14]$. In the case of Au catalyst Wu et al. [28] pointed out that smaller metal particles induce more negative Fermi level shift than the larger particles. In addition the surface plasmon resonance absorption may also contribute to the total absorption thereby to the enhanced photoactivity of $\mathrm{Au} / \mathrm{TiO}_{2}$ catalyst $[17,23]$. As the work function of Au metal is higher $(5.16 \mathrm{eV})$ than that of $\mathrm{TiO}_{2}(4.6 \mathrm{eV})$, we can expect the transfer of electrons from $\mathrm{TiO}_{2}$ to metal at the $\mathrm{Au} / \mathrm{TiO}_{2}$ interface contributes also to the 

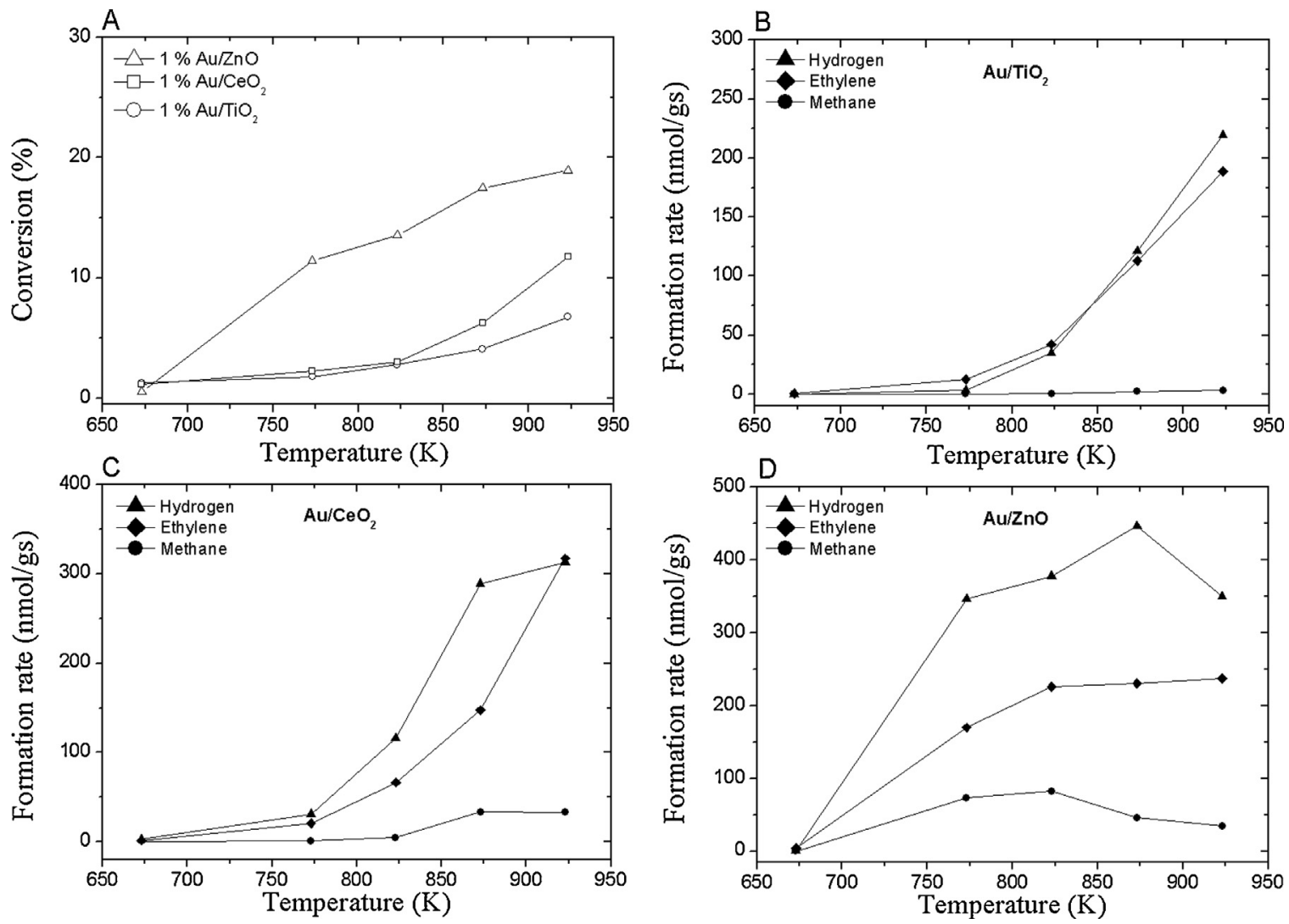

Fig. 3. Effect of support on the thermal decomposition of $\mathrm{C}_{2} \mathrm{H}_{6}$ from $\mathrm{Au} / \mathrm{ZnO} \mathrm{Au} / \mathrm{CeO}_{2}$, and $\mathrm{Au} / \mathrm{TiO}_{2}$.
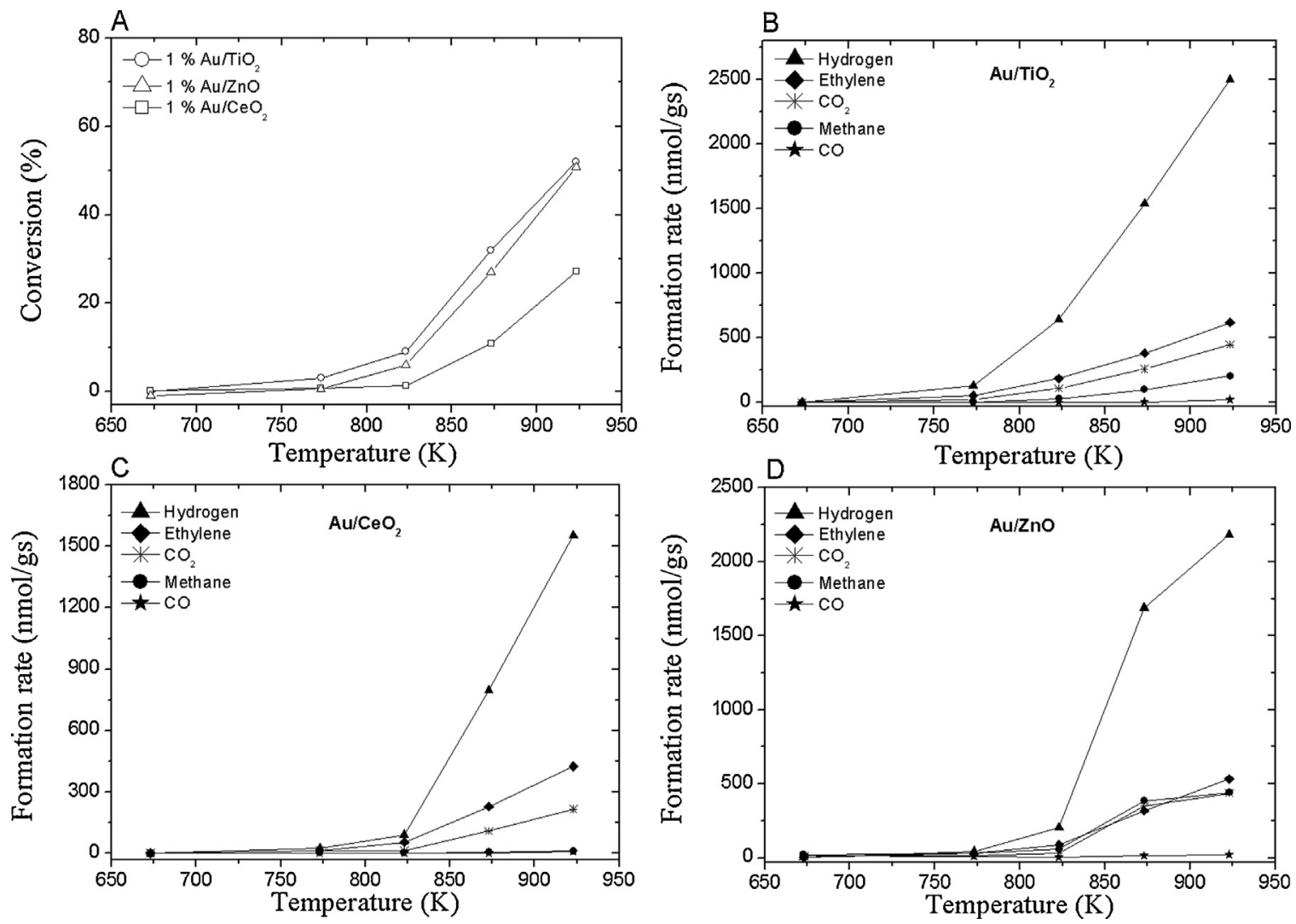

Fig. 4. Effect of $\mathrm{H}_{2} \mathrm{O}$ on the decomposition of $\mathrm{C}_{2} \mathrm{H}_{6}$ catalyzed by supported Au catalysts. 

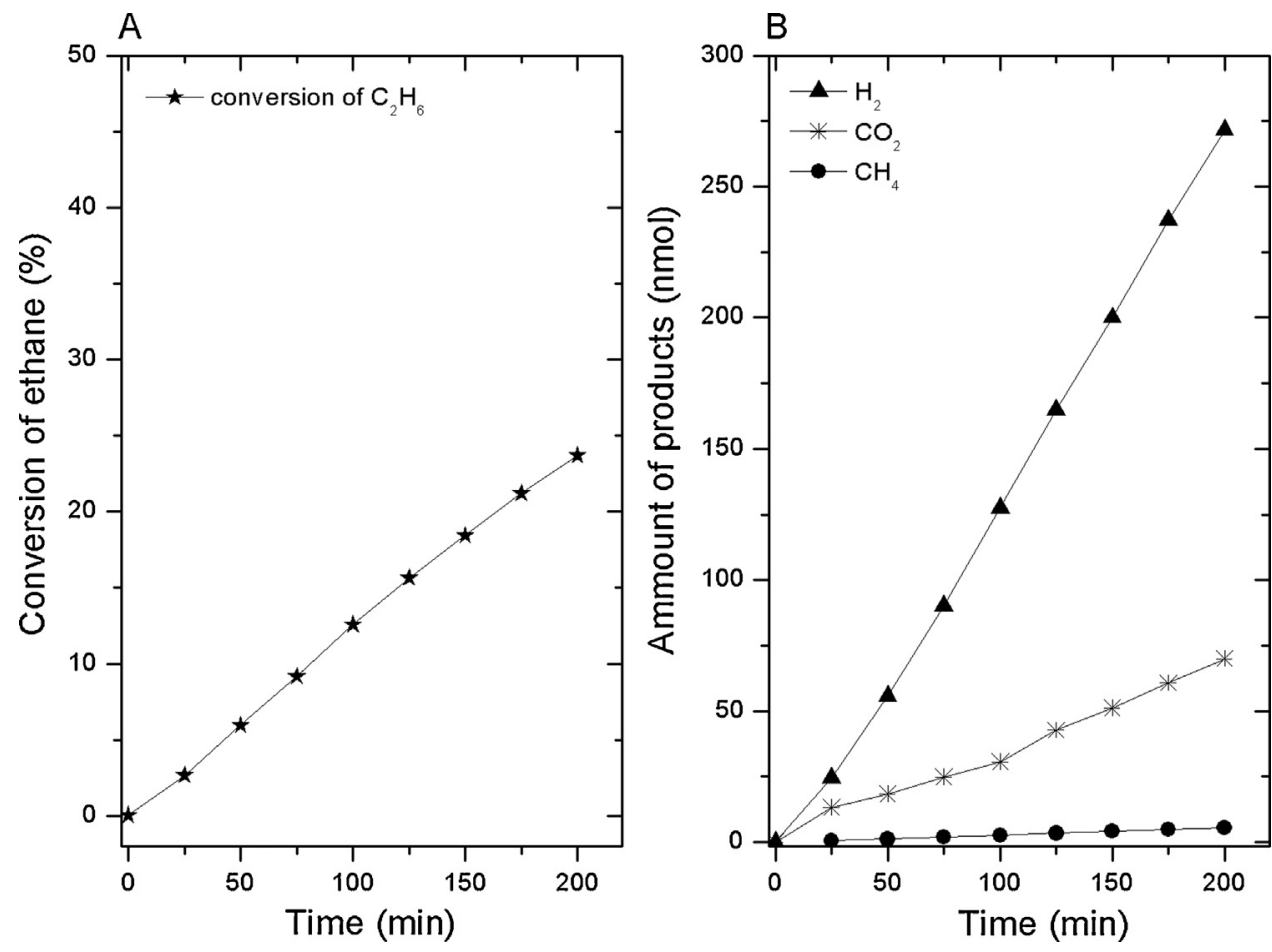

Fig. 5. Photocatalytic reaction of $\mathrm{C}_{2} \mathrm{H}_{6}$ in the presence of $\mathrm{H}_{2} \mathrm{O}$ on $\mathrm{Au} / \mathrm{TiO}_{2}$ catalyst.

enhanced activation of adsorbed molecules. The role of the electron transfer in the enhanced catalytic effect of $\mathrm{TiO}_{2}$ supported metals catalysts has been assumed and confirmed long time ago [24-27] and this idea has been generally used since then.

As regards the further steps we could assume the decomposition of $\mathrm{C}_{2} \mathrm{H}_{5}$ radical to $\mathrm{C}_{2} \mathrm{H}_{4}$

$\mathrm{C}_{2} \mathrm{H}_{5(\mathrm{a})}=\mathrm{C}_{2} \mathrm{H}_{4(\mathrm{~g})}+\mathrm{H}_{(\mathrm{a})}$

or as was found on many metal surfaces [29,30], its recombination

$2 \mathrm{C}_{2} \mathrm{H}_{5(\mathrm{a})}=\mathrm{C}_{4} \mathrm{H}_{10(\mathrm{a})}$

The fact that neither $\mathrm{C}_{2} \mathrm{H}_{4}$ nor $\mathrm{C}_{4} \mathrm{H}_{10}$ was detectable in the products suggests that the lifetime of transiently formed $\mathrm{C}_{2} \mathrm{H}_{5}$ or $\mathrm{C}_{\mathrm{x}} \mathrm{H}_{\mathrm{y}}$ is very short, and instead of their coupling reactions they underwent fast photo-generated degradation resulting in some kind of carbonaceous deposit onto the catalyst.

$\mathrm{C}_{2} \mathrm{H}_{5(\mathrm{a})}=\mathrm{C}_{(\mathrm{s})}+2.5 \mathrm{H}_{2}$

It is an open question how the $\mathrm{H}_{2} \mathrm{O}$ participates in the photocatalytic process. A separate study on the photolysis of $\mathrm{H}_{2} \mathrm{O}$ on the same $\mathrm{Au} / \mathrm{TiO}_{2}$ catalyst indicated that illumination induces only a very slight decomposition of $\mathrm{H}_{2} \mathrm{O}$, less than $2 \%$. The possible reason is that the product of dissociation of $\mathrm{H}_{2} \mathrm{O}$, very likely $\mathrm{O}$ atoms formed in the recombination of $\mathrm{OH}$ groups

$2 \mathrm{OH}_{\mathrm{a}}=\mathrm{H}_{2} \mathrm{O}+\mathrm{O}$

remain the surface occupying the active center. We assume that in the case of $\mathrm{TiO}_{2}$-containing sample the oxygen vacancies are the active centers for this process. The fact that $\mathrm{ZnO}$ does not contain $O$ vacancy, but $Z n$ excess occupies interstitial position in the lattice may be one of the reasons of the less activity of $\mathrm{Au} / \mathrm{ZnO}$ compared to $\mathrm{Au} / \mathrm{TiO}_{2}$.

\section{Conclusions}

(i) n-type oxides $\left(\mathrm{TiO}_{2}, \mathrm{ZnO}, \mathrm{CeO}_{2}\right)$ only slightly catalyses the thermal and the photoreaction of $\mathrm{H}_{2} \mathrm{O}+\mathrm{C}_{2} \mathrm{H}_{6}$.

(ii) Deposition of $\mathrm{Au}$ on the above oxides enhances the thermal reaction of $\mathrm{H}_{2} \mathrm{O}+\mathrm{C}_{2} \mathrm{H}_{6}$ at very high temperature; the conversion exceeds $40 \%$ on the most active catalyst at $900 \mathrm{~K}$

(iii) Illumination, however, induces the $\mathrm{H}_{2} \mathrm{O}+\mathrm{C}_{2} \mathrm{H}_{6}$ reaction over $\mathrm{Au} / \mathrm{TiO}_{2}$ even at room temperature resulting in $20 \%$ conversion of $\mathrm{C}_{2} \mathrm{H}_{6}$ in 200 min yielding $\mathrm{H}_{2}$ and some $\mathrm{CH}_{\mathrm{x}}$ fragments.

\section{Acknowledgement}

This work was supported by the Hungarian Academy of Sciences.

\section{References}

[1] D.M. Bibby, C.D. Chang, R.F. Howe, S. Yurchak (Eds.), Methane Conversion: Studies on Surface Science and Catalysis, Vol. 36, Elsevier, Amsterdam, 1998

[2] J.R. Rostrup-Nielsen, Syngas for $C_{1}$-chemistry: limits of the steam reforming process, Stud. Surf. Sci. Catal. 36 (1988) 73-78.

[3] J.R. Rostrup-Nielsen, K. Aasberg-Petersen, P.S. Schoyube, The role of catalysis in the conversion of natural gas for power generation, Stud. Surf. Sci. Catal. 107 (1997) 473-488.

[4] Y. Ono, Transformation of lower alkanes into aromatic hydrocarbons over ZSM-5 zeolites, Catal. Rev. Sci. Eng. 34 (1992) 179-226.

[5] F. Solymosi, et al., Molecular chemistry of alkane activation, in: E.G. Derouane (Ed.), Aromatization of Hydrocarbons on Supported $\mathrm{Mo}_{2} \mathrm{C}$ Catalysts, Sustainable Strategies for the Upgrading of Natural Gas: Fundamentals, Challenges and Opportunities, Springer, 2005, pp. 25-50.

[6] F. Solymosi, P. Tolmacsov, T. Süli Zakar, Dry reforming of propane over supported Re catalyst, J. Catal. 233 (2005) 51-59.

[7] A. Tóth, G. Halasi, F. Solymosi, Reactions of ethane with $\mathrm{CO}_{2}$ over supported Au, J. Catal. 330 (2015) 1-5.

[8] A. Linsebigler, G. Lu, J.T. Yates Jr., Photocatalysis on $\mathrm{TiO}_{2}$ surfaces: principles: mechanisms and selected results, Chem. Rev. 95 (1995) 735-758.

[9] M.R. Hoffmann, S.T. Martin, W. Choi, D.W. Bahnemann, Environmental applications of semiconductor photocatalysis, Chem. Rev. 95 (1995) 69-96.

[10] A.A. Ismail, D.W. Bahnemann, I. Bannat, M. Wark, Gold nanoparticles on mesoporous interparticle networks of titanium dioxide nanocrystals for enhanced photonic efficiencies, J. Phys. Chem. C 113 (2009) 7429-7435. 
[11] K. Wada, K. Yoshida, T. Takatani, Y. Watanabe, Selective photo-oxidation of light alkanes using solid metal oxide semiconductors, Appl. Catal. A: Gen. 99 (1993) 21-36.

[12] C.T. Brigden, S. Poulston, M.V. Twigg, Photo-oxidation of short-chain hydrocarbons over titania, Appl. Catal. B: Environ. 32 (2001) 63-71.

[13] W.R. Murphy, T.F. Veerkamp, T.W. Leland, Effect of ultraviolet radiation on zinc oxide catalysts, J. Catal, 43 (1976) 304-321.

[14] M. Alvaro, B. Cojocaru, A.A. Ismail, N. Petrea, B. Ferrer, F.A. Harraz, V.I. Parvulescu, H. Garcia, Visible-light photocatalytic activity of gold nanoparticles supported on template-synthesized mesoporous titania for the decontamination of the chemical warfare agent Soman, Appl. Catal. B: Environ. 99 (2010) 191-197.

[15] G. Halasi, A. Tóth, T. Bánsági, F. Solymosi, Production of $\mathrm{H}_{2}$ in the photocatalytic reactions of ethane on $\mathrm{TiO}_{2}$-supported noble metals, Int. J. Hydrogen Energy 41 (2016) 13485-13492.

[16] G. Schubert, A. Gazsi, F. Solymosi, Photocatalytic decomposition and oxidation of dimethyl ether over $\mathrm{Au} / \mathrm{TiO}_{2}$, J. Catal. 313 (2014) 127-134

[17] A. Primo, A. Corma, H. Garcia, Titania supported gold nanoparticles as photocatalyst, Phys. Chem. Chem. Phys. 13 (2011) 886-910.

[18] D.W. Bahnemann, Mechanisms of organic transformations on semiconductor paritcles, in: E. Pelizzetti, M. Schiavello (Eds.), Photochemical Conversion and Storage of Solar Energy, Kluwer Academic Publishers, Dordrecht, 1991, pp. 251-276.

[19] M. Anpo, Photocatalysis on small particle $\mathrm{TiO}_{2}$ catalysts - reaction intermediates and reaction-mechanisms, Res. Chem. Intermed. 11 (1989) 67-106.
[20] H. Sakurai, M. Haruta, Carbon dioxide and carbon monoxide hydrogenation over gold supported on titanium iron, and zinc oxides, Appl. Catal. A: Gen. 127 (1995) 93-105.

[21] H.J. Freund, Oxygen activation on oxide surfaces: a perspective at the atomic level, Catal. Today 238 (2014) 2-9.

[22] G. Pacchioni, H.J. Freund, Electron transfer at oxides surfaces. The MgO paradigm: from defects to ultrathin films, Chem. Rev. 113 (2013) 4035-4072.

[23] V. Subramanian, E.E. Wolf, P.V. Kamat, Catalysis with $\mathrm{TiO}_{2}$ /gold nanocomposites. Effect of metal particle size on the Fermi level equilibration, J. Am. Chem. Soc. 126 (2004) 4943-4950.

[24] G.M. Schwab, J. Block, D. Schultze, Kontaktkatalytische Verstärkung durch dotierte Träger, Angew. Chem. 71 (1959) 101-104.

[25] Z.G. Szabó, F. Solymosi, Influence of the defect structure of support on the activity of catalyst, Actes Congr. Intern. Catalyse, $2^{\mathrm{e}}$ Paris, 1960, 1961, 1627-1651.

[26] F. Solymosi, Importance of the electric properties of supports in the carrier effect, Catal. Rev. 1 (1968) 233-255.

[27] F. Solymosi, Comments on: electronic effects in strong metal-support interactions on titania-deposited metal catalysts, J. Catal. 94 (1985) 581-585.

[28] G. Wu, T. Chen, W. Su, G. Zhou, X. Zong, Z. Lei, C. Li, H2 production with ultra-low $\mathrm{CO}$ selectivity via photocatalytic reforming of methanol on $\mathrm{Au} / \mathrm{TiO}_{2}$ catalyst, Int. J. Hydrogen Energy 33 (2008) 1243-1251.

[29] F. Solymosi, Thermal stability and reactions of $\mathrm{CH}_{2}, \mathrm{CH}_{3}$ and $\mathrm{C}_{2} \mathrm{H}_{5}$ species on the metal surfaces, Catal. Today 28 (1996) 193-203.

[30] F. Zaera, Determination of the mechanism for ethyldiyne formation from chemisorbed ethylene on transition metal surfaces, J. Am. Chem. Soc. 111 (1989) 4240-4244. 